\title{
Becoming Arab in London: Performativity and the Undoing of Identity
}

Rhys $\mathrm{H}$. Williams

Loyola University Chicago, rwilliams7@luc.edu

Follow this and additional works at: https://ecommons.luc.edu/soc_facpubs

Part of the Sociology Commons

\section{Author Manuscript}

This is a pre-publication author manuscript of the final, published article.

\section{Recommended Citation}

Williams, Rhys H.. Becoming Arab in London: Performativity and the Undoing of Identity. Contemporary Sociology: A Journal of Reviews, 46, 6: 622-623, 2017. Retrieved from Loyola eCommons, Sociology: Faculty Publications and Other Works, http://dx.doi.org/10.1177/0094306117734868b

This Book Review is brought to you for free and open access by the Faculty Publications and Other Works by Department at Loyola eCommons. It has been accepted for inclusion in Sociology: Faculty Publications and Other Works by an authorized administrator of Loyola eCommons. For more information, please contact ecommons@luc.edu.

\section{(c) () $९$}

This work is licensed under a Creative Commons Attribution-Noncommercial-No Derivative Works 3.0 License. (C) American Sociological Association 2017 
Becoming Arab in London: Performativity and the Undoing of Identity, by Ramy M.K. Aly. London: Pluto Press, 2015. 255 pp. ISBN 9780745333588.

Rhys H. Williams

Loyola University Chicago

Rwilliams7@luc.edu

It is becoming increasingly common to treat what sociologists used to call "ascribed statuses" statuses and identities we were 'born with' - as things that must be "accomplished" and continuingly reaccomplished. Thus, the idea of "doing" rather than just "being" is applied to gender, to ethnicity or race, or more recently to religion. For Ramy Aly, "One is not born an Arab in London, instead Arabness is a process of becoming through acts, enunciations, objects, spaces, bodies and settings ... " (p.1) - in other words, through the performance of culture, or cultural performativity, depending on the nuances of differing theoretical approaches. Following this performative turn, Aly asks "how is Arabness done in London" (p.10) with the result being the production of a cultural product, "the Arab."

Aly is particularly interested in what he calls "everyday Arabness," and thus eschews formal organizations, civic campaigns, or the self-consciously political discourses of "pan-Arabism" for the ways in which discourses are formulated, used, borrowed, and altered in restaurants, gatherings of friends, parties, informal public settings and the like. Particularly important were "Shisha (hookahs used to smoke sweet molasses tobacco) cafes" as nodal points - public places that entail a performativity for others, but others who seem to share something of a common cultural vocabulary and - crucially - want you to succeed in the performance as the people involved all learn from and with each other. The cafes are a certain 'safe space' (my term, not Aly's) even as they are public. The chapter on café sociability shows many ways in which being Arab in London is expressed; for example, Shisha and drinks are ordered in Arabic, but the banter around card games and other conversations are usually in English with Arabic sayings or phrases thrown in. No alcohol is served, but non-alcoholic malt drinks, served in what 
look like beer bottles, are popular with young men (and the cafes are primarily but not exclusively male spaces).

Aly notes that this type of everyday socializing could potentially be done in other settings, such as someone's flat, a pub, or a bistro. But most of the 20-something, early career men were unmarried and still lived with their parents (and seemingly expected to until marriage and starting their own families), and they didn't drink alcohol, even if not carefully religiously observant in other ways. In sum, other public settings did not have the clear "home-from-home" (p.110) atmosphere or role as did the Shisha cafes. Further, as Aly notes, there are few visual representations of "Arab culture" more recognizable than the hookah, and it also carries a certain connection to Orientalist decadence in its association with opium or hashish. Thus, even as these spaces are familiar and safe for Arab-speaking immigrants and their second generation, they carry meanings beyond that for many Westerners.

As such, Aly recognizes that the spaces he investigates at the everyday level exist within conditions of migration and transnationalism. He does not neglect how historical forces have shaped Arab London in a chapter on the history of migration, war, and the vicissitudes of the world economy. London has a wide variety of people who are Arab speakers, who have been in the city for varying lengths of time. In London, he notes, "dialects, traditions, religion, politics, food and music are counterexposed, not only in an introverted Arab-Arab fashion but within the context of local and global cultural, economic and political flows." (p.13). Following this history, and partly shaped by his focus on second generation and ' 1.5 ' generation young adults, is a consideration of schooling and processes of youth socialization.

Aly's performative and inductive approach leads him to two areas of explicit performance, dance and visual representation. He investigates dance classes at a London university, as well as attending some social events based around baladi (folk dancing) and professional belly dancing. They vary in their styles and meanings based on contexts - such as how connected they are to familial 
spheres - as well as the varying in erotic connotations. In almost every place, however, there is a peer policing of sexuality, gender, and heteronormativity. Further, the explicitness and formality of the steps and performance vary as well, reinforcing Aly's overall point about the nuance and contextualized nature of "choreographing Arabness" (p.133).

The focus on belly dancing leads smoothly into the consideration of visual representation and the Orientalist gaze, as the chapter provides numerous examples of posters advertising parties that use women belly dancers as the visual sell. Then Aly offers an analysis of photographs and drawings that appeared in a local (if short lived) Arab community magazine. As with the analysis of dance, the visual images appropriate and also try to re-inscribe the Orientalist gaze of what constitutes "Arab." Both chapters have significant engagements with aesthetic theory and cultural studies as well as reports from ethnographic experiences. I admit that I occasionally tired of excursions into what this or that anthropologist said in the past about Arab dance or other features of culture. That said, this is theoretically informed ethnographic work at every level. I just found the people he hung out with so interesting; I liked hearing from them.

In all, there is much that is interesting in Aly's ethnographic reporting, but in many ways not particularly surprising. With appropriate variation, one might imagine similar books about becoming Arab in New York, or becoming Hispanic in Chicago, or becoming Maghrébin in Paris. The contribution here, at least to scholars, is the continual engagement with theory, obviously centered on Judith Butler, but also with Margaret Mead, Victor Turner, Erving Goffman, Paul Gilroy, Edward Said, and debates about "performativity" versus "performance" and "constructionist" versus "neo-structuralist." Aly weaves carefully between the poles, and falls back on the specifics of his experience to balance flights of theoretical abstraction. This would make the volume pretty hard going for many undergraduate classes. But graduate students interested in migration, post-colonial studies, sociology of culture, and contemporary theory will find much to wrestle with and learn from. 